\title{
FURTHER EVIDENCE FOR A “LATE ASSYRIAN DRY PHASE” IN THE NEAR EAST DURING THE MID-TO-LATE SEVENTH CENTURY B.C.?
}

\author{
By AdAM W. SCHNEIDER AND Selim F. AdALI ${ }^{1}$
}

\begin{abstract}
In a recent paper published in the journal Climatic Change, we put forward the hypothesis that drought and overpopulation played an important, if indirect, role in shaping the sudden decline of the Assyrian Empire during the mid-to-late seventh century в.с. This argument was partly predicated on five paleoclimatic proxy records for conditions in different parts of the northern Near East during the first millennium B.C., each of which indicates that relatively arid conditions affected much of the region during the seventh century B.C., especially during its middle decades. Here, we revisit the textual and paleoclimatic proxy evidence for a period of drought in more depth to examine whether this evidence does in fact support the climatic component of our hypothesis. In this paper, we show that the available proxy evidence supports the notion that there was some kind of regional climatic perturbation that affected much of the Near East during the latter half of the seventh century B.C., which caused conditions in many parts of the region to become more arid. The strongest signal for this short-term episode of aridification, which we have termed the "Late Assyrian Dry Phase," is observed at approximately $650-600$ в.с. These proxies thus corroborate and provide the background for the Neo-Assyrian textual evidence for drought during the mid-seventh century в.C.
\end{abstract}

\section{Introduction}

During the past two decades, a much clearer understanding of the Mid-to-Late Holocene climate history of the Near East has emerged. This improvement derives in large part from studies that have explicitly attempted to resolve a scholarly archaeological and historical conversation about the role, if any, that climate change may have had in the collapse of ancient Near Eastern societies. Much of this discussion has focused on whether long-term droughts caused the fall of the Akkadian Empire in Mesopotamia in c. 2200 B.c. (e.g., Weiss et al. 1993), and/or the sudden political decline of the great Late Bronze Age empires of Egypt, Assyria, and the Hittites shortly after 1200 B.C. (e.g., Neumann and Parpola 1987; Kaniewski et al. 2008, 2010; Cline 2014).

In a recent paper, we explored the potential role of climate change in the sudden collapse of the Neo-Assyrian Empire, which dominated the Near East between $c .900-c .650$ B.C. (Schneider and Adal1 2014). In that study, we proposed the hypothesis that a period of drought that took place during the 650s B.C., the overpopulation of the Assyrian core area, and other structural factors, formed a "perfect storm" of conditions which greatly influenced the series of events that led to the political decline of that empire over the span of just a few decades.

In this article, we argue that multiple sources of Late Holocene paleoclimatic information for the Near East provide evidence of a short term period of drier conditions in much of the region during the middle decades of the seventh century B.C., centred at $c$. 650 B.C. Minimally, this climatic trend is reflected in eight paleoclimatic proxy records obtained from sources in western and central Anatolia, the Levant, and western Iran. Moreover, the period of increased aridity indicated by these data finds further support in the royal correspondence of the Assyrian Empire during this time, offering intriguing evidence of worsening environmental conditions in the Assyrian heartland region of northern Iraq during the mid-seventh century B.c. Because this climatic perturbation is attested in Assyrian historical sources as well as regional proxy records, we have chosen to call this episode "Late Assyrian Dry Phase".

\footnotetext{
${ }^{1}$ We would like to express our sincere thanks to Dr. Guillermo Algaze, Dr. H. Nüzhet Dalfes, and Dr. Bülent Arıkan for their thoughtful comments on early drafts of this paper. We would also like to extend our appreciation to
}

the Research Center for Anatolian Civilizations and Koç University, and especially the staff of the RCAC Library, for their support of our research. 


\section{Modern Climate of the Near East}

Before examining the evidence for climatic conditions in the Near East during the seventh century B.C., it is first necessary to say something about the present-day climate of the region. In general, the Near East can be broadly classified as semi-arid. Precipitation is highly seasonal, with the majority of it falling as a result of mid-latitude cyclones that form over the Mediterranean during the winter months (November-March). The highly seasonal character of rainfall is largely a result of the presence of large, semi-permanent anticyclones that form over the Azores, which direct Atlantic air masses away from the Mediterranean Basin and into northern Europe (Cullen et al. 2002). Although they can form during any time of year, these anticyclones occur with greater frequency during the summer and early autumn than in the winter, resulting in the pattern of dry, hot summers and cool, wet winters which is characteristic of Mediterranean climates (Katsoulis et al. 1998).

These high pressure zones appear to be influenced by the weather system known as the North Atlantic Oscillation (NAO), which seems to govern two major pressure systems in the North Atlantic Ocean: the high pressure anticyclonic system over the Azores, and a low pressure system that forms off the coast of southern Greenland. In years when the high and low pressure systems are weak ("negative NAO years"), Atlantic moisture travels more or less unimpeded from the Atlantic and across the Mediterranean, resulting in increased winter storm activity in southern Europe and the Near East; in years when they are more intense ("positive NAO years"), moisture is shunted instead into Scandinavia and Northern Europe, and the Mediterranean winter season is relatively dry (Cullen and deMenocal 2000: 859). Because of its influence over winter precipitation in the Taurus Mountains of southeastern Turkey, where the headwaters of both the Euphrates and the Tigris are located, the NAO also appears to have affected the annual discharge of the two rivers considerably before they were dammed during the late twentieth century; Cullen and deMenocal report that during the period 1929-1972, the Tigris-Euphrates drainage exhibited a nearly six fold variation in annual flow rates (Cullen and deMenocal 2000: 856).

While climate in this area is largely controlled by the NAO, other anisotropic factors such as topography, elevation, continentality, and latitudinal position can cause local (and regional) conditions to vary considerably. Considerable amounts of mean annual precipitation $(>500$ millimetres per year) fall at higher elevations in the Eastern Taurus and Zagros mountain ranges, while in the steppe-deserts of eastern Syria and northern Iraq (known as the Jazirah), mean annual rainfall is below 250 millimetres per year, and is therefore insufficient to support cereal agriculture without irrigation (Wilkinson 2000). There is a strong north-south precipitation gradient throughout the Near East, with conditions being comparatively humid in the north and drier in the south. For example, Wilkinson notes that in the Turkish Euphrates Valley, "the Anti-Taurus mountains and foothills receive more than double the rainfall of the Syrian-Turkish border near Harran" (Wilkinson 1990: 13). There is also a strong east-west precipitation gradient in the region, with the Mediterranean coastal areas receiving more annual rainfall than inland areas, such as the alluvial plains of Iraq (Trigo et al. 2010: 1246).

The Near East is a climatically sensitive region, and there is a high interannual variability in the amount of precipitation that it receives each year. This variability is particularly pronounced in the inland areas of southeastern Turkey, northern Syria, and northern Iraq (which are collectively often referred to as northern or Upper Mesopotamia). By way of example, in the southeastern Turkish province of Adiyaman, modern annual precipitation rates can vary by as much as fiftynine per cent (Türkeş 1998: 659). However, even in years that are unusually dry (or wet), the highly seasonal nature of annual precipitation appears to remain unchanged; these years are generally characterized by less (or more) precipitation than average during the NDJFM period, rather than increased or decreased rainfall at other times of the year (Trigo et al. 2010: 1248).

Throughout the Near East, droughts are a frequent occurrence-a fact which is amply demonstrated in the modern climate histories of Turkey and Iraq. In Turkey, three major dry periods took place between 1930 and 1993 (1955-1961; 1970-1974; 1982-93, minus two wetter years in 1987 and 1988), with severe nationwide droughts occurring in 1973, 1984, 1989, and 1990 (Türkeş 1996). In Iraq, which on the whole receives less precipitation than Turkey, the climatic 
situation is more precarious. In Iraq, a thirty-year dry period took place between 1980-2010. During this interval, severe nation-wide drought events occurred in 1983, 1998-2000, and 2008, and localized drought events that affected one or more regions of Iraq occurred during a further seven years of that same period (1987, 1989-1990, 2001-2005, 2007, and 2009) (Al-Timimi and Al-Jiboori 2013). Thus, in Turkey, four out the twenty-two drier than average years ( 18 per cent) were characterized by nationwide drought events while in Iraq, there were four nationwide drought event years in a thirty-year period ( $\sim 13$ per cent), but if one also counts regional drought events as well, the severely dry conditions prevailed in at least part of Iraq in half of the thirty years.

In addition to illustrating that the Near East is frequently beset with droughts, these data also demonstrate that, in the case of both modern Turkey and modern Iraq, severe drought events do not occur in isolation, but rather within multi-year dry periods. Moreover, because the current climatic patterns of the Eastern Mediterranean region have been broadly similar for the last 5000 years (Roberts et al. 2001: 721), the character of dry periods in the modern Near East that has just been described above is likely to have been very similar to those that occurred during the first millennium B.C. This last point is of particular significance, and we will return to it later in this analysis.

\section{Paleoclimate proxy evidence for aridification in the Near East during the seventh century B.C.}

A number of paleoclimate proxy records have preserved information about conditions in other parts of the Near East during the seventh century B.c. In the analysis that follows, local records of first millennium conditions from eight archives located across the region (see Fig. 1) were compared so as to reconstruct climatic trends during the first half of the millennium. ${ }^{2}$ Two different types of paleoclimate proxy evidence were employed in this regional reconstruction: diachronic analyses of sedimentary compositions from lake and marine sediment core samples, and stable oxygen isotope ratios obtained from sedimentary core samples or cave speleothems. We focused on these particular lines of evidence specifically, because they provide proxy data "which can be unambiguously attributed to climatic forcing" (Roberts et al. 2011: 3). Four records of each type were incorporated into the regional paleoclimate sequence.

Evidence for early first millennium B.C. climate inferred from sediment compositions. One very effective way to access information about ancient climates is through the biogeochemical analysis of sediment samples obtained from lakebeds or the sea floor (sometimes called "sediment archives"). Changes in the physical or chemical composition of sediments can betoken changes in climate during the past that affected, among other things, the level of the lake or sea, as well as the relative salinity of the lake water, which are themselves indicators of fluctuations or shifts in climate over time. An advantage of this particular type of proxy record is that there are a number of different biogeochemical properties of sediments which can be analyzed using the same samples; on the other hand, they tend to be at a lower spatial resolution, and because some bodies of water are much more sensitive to small shifts in climate than others, the relative sensitivity of each to changes in ambient temperature or humidity must be taken into account when comparing different sediment proxy records.

Multiple sediment archives from a variety of locations across the Near East indicate that a climatic fluctuation occurred during the seventh century B.C. resulting in a temporary episode of aridification in many parts of the region. A good example is the sediment archive obtained from Tecer Lake, a shallow lake located near modern Sivas in the northeastern part of the central Anatolian highlands (Kuzucuoğlu et al. 2011). The age-depth model of this sequence is based on 11 AMS ${ }^{14} \mathrm{C}$ dates obtained from pollen grains that were extracted from the sediment core at regular $50 \mathrm{~cm}$ intervals; the mean $1-\Sigma$ error range for these AMS ${ }^{14} \mathrm{C}$ dates was 71.91 years (see Table 1; also

\footnotetext{
${ }^{2}$ Although five of these proxy records- those from Eski Acıgöl, Lake Iznik, the Rumailiah River, Tecer Lake, and Lake Zeribar (Zarivar)-were briefly discussed in our
}

previous article (Schneider and Adalı 2014: 436-37), they will be revisited here in greater detail. 


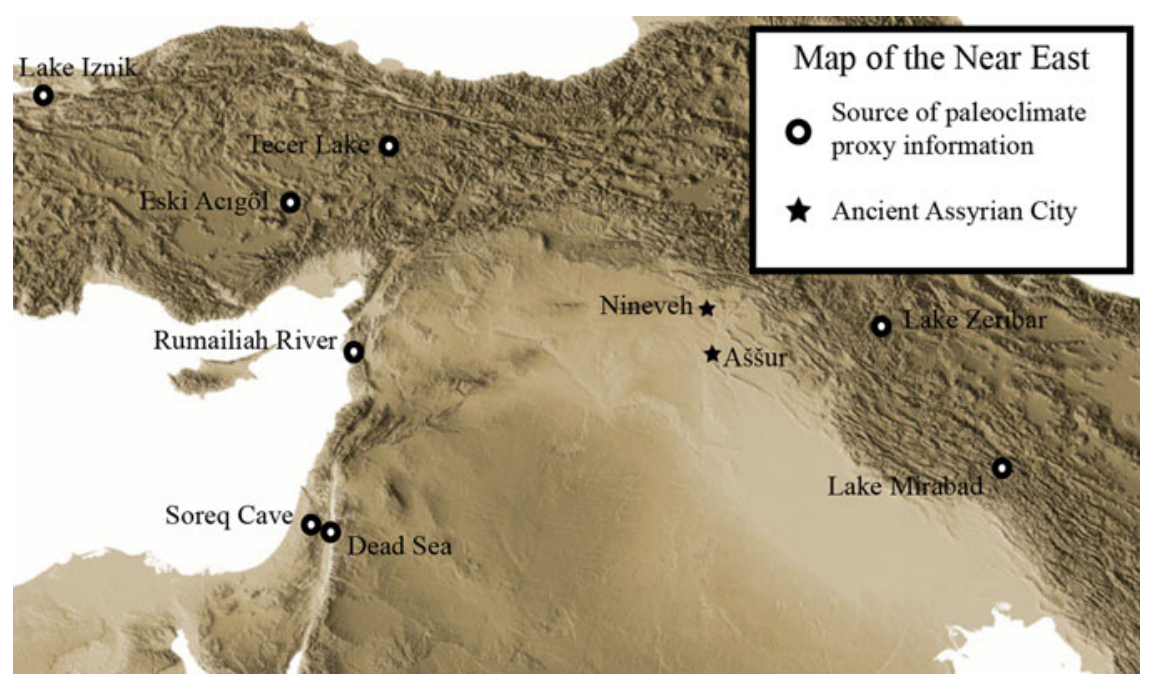

Fig. 1 Map of the Near East, including the locations of sites discussed in the text

Kuzucuoğlu et al. 2011: Table 2). Proxy data for conditions in the vicinity during the mid-first millennium B.C. are recorded in a unit of the Tecer sequence dubbed Phase V, which has been dated to $c$. 850-70 B.C. From the lack of either aragonite or gypsum in the clay of Phase V, Kuzucuoğlu et al. inferred that conditions were generally humid in the area of the lake during this time (ibid: 183). However, the presence of a six to seven centimetre thick calcite crust in sediment layers dated to $c$. 670-620 B.C. indicates that the middle of the seventh century B.C. was characterized by "high-magnitude and repeated water-table variations due to drastic episodes of summer desiccation" (ibid). After this period, humid conditions resumed again for the remainder of the millennium, save for two brief arid events identified at $c .450$ B.c. and c. 300 B.C., during which three to seven centimetre calcite crusts were also deposited in the lakebed sediments.

The Tecer Lake sediment sequence provides evidence of the Late Assyrian Dry Phase at a particularly high temporal resolution, but it is not the only Anatolian lake to yield paleoclimate proxy evidence for desiccation during the mid-seventh century B.C. A contemporaneous onset of drier conditions in northwestern Anatolia is also attested in the sediment lithology of Lake Iznik, situated near the modern city of Iznik (Ülgen et al. 2012). The sedimentary sequence from Lake Iznik for the seventh century B.c. is divided between by two distinct subunits in the lakebed sediment sequence: Zone 5 (c. 1250-650 B.c.) and Zone 6 (c. 650-1 B.c.). From their observations of the sediment lithology in Zone 5, Ülgen et al. concluded that this period was a multi-century humid phase, while a shift towards cooler and drier conditions in northwestern Anatolia at the beginning of Zone 6 (i.e., in c. 650 B.c.) was inferred from numerous changes in the sediments, including an increase in total inorganic content (TIC), and in concentrations of aragonite and calcite within the Zone 6 sediments (ibid: 97). Because the age-depth model of this sequence is based on nine plant and bulk organic carbon AMS ${ }^{14} \mathrm{C}$ dates, which exhibited a comparatively small mean error of 43.94 (see Table 1; also Ülgen et al. 2012: Table 3), the timing for the onset of the climatic shift inferred from the geochemical changes that occur between Zones 5 and 6 in the Iznik sequence can be reliably placed in the middle decades of the seventh century B.C.

Two further sediment sequences from the Levant also exhibit a shift towards greater aridity during the middle centuries of the first millennium B.c. The first of these was inferred from changes in the sedimentary archive of the Rumailiah River near the ancient site of Tell Tweini/Gibala, which is located on the coastal plain of northern Syria near modern Jableh. Changes in geochemical composition of sampled alluvial sediments from the Rumailiah sequence signal a shift towards increased aridity at c. 600 B.C.; unfortunately, however, because this shift occurred at the end of the sequence, it is not possible to determine the duration of this shift in the Rumailiah sedimentary 
TABLE 1. Information about the chronometric basis for the age models used to anchor the eight proxy records examined in this study

\begin{tabular}{|c|c|c|c|c|c|c|c|}
\hline Site & Type & $\begin{array}{l}\text { \# Overall } \\
\text { Dates }\end{array}$ & $\begin{array}{l}\text { Oldest } \\
\text { date } \\
\text { (cal. BP) }\end{array}$ & $\begin{array}{l}\text { Youngest } \\
\text { date } \\
\text { (cal. BP) }\end{array}$ & $\begin{array}{l}\text { \# 1st mil. } \\
\text { BC Dates }\end{array}$ & Mean Error & Source \\
\hline Dead Sea & AMS & 36 & $3703 \pm 37$ & $96 \pm 36$ & 15 & $70.972222(1 \Sigma)$ & $\begin{array}{l}\text { Bookman } \\
\text { (Ken-Tor) et al., } \\
\text { 2004: Tables 1-3 }\end{array}$ \\
\hline $\begin{array}{l}\text { Eski } \\
\text { Acıgöl }\end{array}$ & TIMS & 6 & $\begin{array}{l}23,200 \\
\pm 2000\end{array}$ & 0 & 0 & 2066.6666666 & $\begin{array}{l}\text { Roberts et al., } \\
\text { 2001: Table } 2\end{array}$ \\
\hline Iznik & AMS & 9 & 4723 & 290 & 2 & 43.94444444 & $\begin{array}{l}\text { Ülgen et al., 2012: } \\
\text { Table } 3\end{array}$ \\
\hline Mirabad & AMS & 3 & 8870 & 360 & 0 & $106.66667(1 \Sigma)$ & $\begin{array}{l}\text { Stevens et al., 2006: } \\
\text { Table } 1\end{array}$ \\
\hline Rumailiah & AMS & 4 & 4050 & 2850 & 1 & $115(1 \Sigma)$ & $\begin{array}{l}\text { Kaniewski et al., } \\
\text { 2008: Table } 1\end{array}$ \\
\hline Soreq & TIMS & 78 & 141,030 & 1210 & 1 & 1.070906667 & $\begin{array}{l}\text { Bar-Matthews } \\
\text { et al., 2002: Table } 2\end{array}$ \\
\hline Tecer & AMS & 11 & 5830 & 670 & 3 & $71.909091(1 \Sigma)$ & $\begin{array}{l}\text { Kuzucuoglu et al., } \\
\text { 2011: Table } 2\end{array}$ \\
\hline Zeribar & AMS & 5 & $\begin{array}{l}16,682- \\
16,092\end{array}$ & $2240 \pm 150$ & 1 & 137.6 & $\begin{array}{l}\text { Stevens et al., 2001: } \\
\text { Table 1 }\end{array}$ \\
\hline
\end{tabular}

archive (Kaniewski et al. 2008). Additionally, it should also be noted that, because the geochronology provided for this sedimentary archive is based on just four AMS ${ }^{14} \mathrm{C}$ dates, and because the mean calibrated $1-\Sigma$ age range of these dates is 115 years (see Table 1; also Kaniewski et al. 2008: 13942), the dates provided for the archive's chronological sequence must be approached with a certain amount of caution.

A lake level reconstruction of the Dead Sea (Bookman (Ken-Tor) et al. 2004) also indicates that the shift towards drier conditions may have taken place somewhat earlier in the Southern Levant than in coastal Syria. The geochronology of this archive was based on over thirty-five AMS ${ }^{14} \mathrm{C}$ dates from organic matter in the sedimentary sequence; the mean $1-\Sigma$ error for the thirty-six samples with calibrated and modelled dates was 70.97 (see Table 1; also Bookman (Ken-Tor) et al. 2004: Tables 1-3). The intrusion of an erosional channel covered by aragonite crusts directly above and below it in the sediment sequence (known as Unconformity B), which was dated to 690-410 B.C., was interpreted as evidence that a sudden and significant drop in the lake level of the Dead Sea took place during this period (ibid: 566). This anomalous feature represents a lowstand in the lake level and probably also a hiatus in sedimentation - one of five in the entire 4000 year sequence reported in the study (ibid: 570) - and is indicative of an approximate 300 year arid period in the vicinity, which began in c. 690 B.C. and continued until centuries after the Assyrian state had been destroyed.

Evidence for early first millennium B.C. climate inferred from stable oxygen isotope records. Stable oxygen isotope ratios are another form of proxy that is particularly useful for paleoclimate reconstruction. Oxygen stable isotope analysis is used to establish the isotopic composition of water which falls as precipitation (i.e., "meteoric water"). Ratios of stable oxygen isotopes in

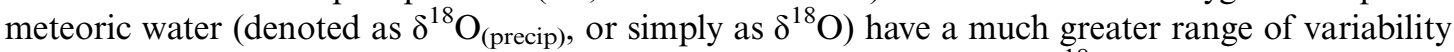
than ocean water, largely as a result of the continuous depletion of ${ }^{18} \mathrm{O}$ in atmospheric water vapour that occurs as clouds cool while they travel over land masses (Dansgaard 1964). Because the oxygen isotope compositions of numerous substances, such as cave speleothems, snail shells, bone, and tooth enamel, can reflect those of meteoric water, the stable oxygen isotope ratios of those other substances can thus provide information about ambient temperature, humidity, precipitation, and seasonality in the past (cf. Gat 1996). Stable isotope data possess two key advantages: 1) they can potentially provide climate proxy data at very high temporal resolutions 
(even at a monthly scale) and reasonably high spatial resolutions; and 2) the physical and chemical reactions that govern how isotope ratios change are universal, which permits comparatively straightforward comparisons between different stable isotope proxies. On the other hand, stable isotopic compositions can sometimes become altered over time-a process called diagenetic contamination - and thus not serve as an accurate reflection of the oxygen isotopic composition of paleorainfall that would otherwise be recorded in the altered substance.

As was the case for the biogeochemical sediment composition proxy records discussed above, multiple Near Eastern stable isotope paleoclimate proxies also provide evidence for a regional climatic perturbation during the mid-to-late seventh century B.C. For example, a stable oxygen isotope analysis of bulk sediments from the lakebed of Eski Acıgöl, a former crater lake located in the central Anatolian highlands approximately 250 kilometres to the southwest of Tecer Lake, shows a slow but steady process of aridification that began at or shortly before $c .850$ B.C. The waters of the lake reached their most evaporatively enriched (with an overall increase in $\delta^{18} \mathrm{O}$ of approximately $+2.5 \%$ ) at $c$. 600 B.C. (cf. Jones and Roberts 2008: fig. 2). Indeed, to judge from the Eski Acigöl sedimentary oxygen isotope ratios, the peak in $\delta^{18} \mathrm{O}$ values at this time indicates that the late seventh century B.C. was one of the driest phases in this vicinity in the entire Holocene oxygen isotope sequence. It must be noted, however, that while these data are a strong indication of intense aridity in the central Anatolian plateau during the middle of the millennium, the U-Th dates which were used to construct U-series age-depth estimates for the lake sediments have relatively large standard errors, and therefore there is some uncertainty regarding the dates for the onset and peak of arid conditions during this period (see Table 1; also Roberts et al. 2001: 724-5, Table 2; Jones and Roberts 2008: 32). However, given that the U-Th dates "form a relatively coherent series" despite the large standard errors (Roberts et al. 2001: 725), and that the period of peak aridity observed in the $\delta^{18} \mathrm{O}$ values at Eski Acıgöl is roughly contemporaneous with evidence for increased aridity observed in other Near Eastern proxy records with more secure chronologies, we feel that the inclusion of these proxy data is justified despite the chronological uncertainty discussed above.

As was the case with the sedimentary archives, the pattern apparent in oxygen stable isotope data is not isolated to Anatolia. On the contrary, to judge from complimentary oxygen stable isotope data from elsewhere in the Near East, the Anatolian data are indicative of a wider climatic phenomenon that took place during the seventh century B.C. A case in point is provided by stable oxygen isotope data from Soreq Cave in central Israel, which indicate that the southern Levant also experienced an intense dry phase during the middle centuries of the first millennium B.c. The stable oxygen isotope record from Soreq is particularly valuable because speleothems from this cave have yielded a very long-term sequence of high-resolution data; consequently, isotope results from this site have become one of the best-known sequences of stable oxygen isotope proxy data in the Near East, and speleothem samples from the cave have been the subject of multiple stable oxygen isotope studies, of which one is particularly pertinent here (Bar-Matthews et al. 2003). This study was chronologically anchored with a U-Th series of dates from speleothem lamina that were analyzed via thermal ionization mass spectrometry (TIMS) in two previous studies (Bar-Matthews et al. 2000; Ayalon et al. 2002). The U-Th geochronology is both continuous and relatively precise: the mean error reported for seventy-eight TIMS dates from Soreq, which span the last 141,000 years, was 1.071 (see Table 1; also Bar-Matthews et al. 2000: Table 2). Thanks to the depth and precision of the geochronological sequence in the Soreq speleothems, Bar-Matthews et al. (2003) were able to demonstrate a robust link between the $\delta^{18} \mathrm{O}$ values from Soreq and those of marine isotopic records of Eastern Mediterranean sea surface temperatures (SST). As a result, they were subsequently able to reconstruct the $\delta^{18} \mathrm{O}$ values for the meteoric water of paleorainfall at Soreq over the course of the Holocene at a centennial scale, from which they were then able to calculate mean annual rainfall amounts at Soreq for the entire Holocene, also at a centennial scale (ibid: 3193-96). The results of this reconstruction of paleorainfall levels at Soreq revealed that the amount of mean annual precipitation at Soreq dropped steadily during the first half of the millennium: by around $c$. 550 в.C., mean annual precipitation levels in central Israel were some 150 millimetres lower than they had been at the start of the millennium, with aridity in the region 
at its most intense between $650-450$ B.C.- a period which is, incidentally, roughly contemporaneous to the AMS-based chronology for Unconformity B in the Dead Sea sedimentary archive. This arid period, in turn, was followed by a return to wetter conditions for the remainder of the millennium. Because the oxygen isotope data from Soreq span the entire Holocene, they also indicate the striking severity of this dry phase in the coastal southern Levant: $\delta^{18} \mathrm{O}$ values for paleorainfall at Soreq were the highest recorded at any point during the past 4500 years (cf. Bar-Matthews et al. 2003: fig. 12a), while the levels of mean annual precipitation during the mid-first millennium B.C. were the lowest for that span, and SST was also unusually high (ibid: fig. 13a).

Further evidence for a climatic perturbation affecting large parts of the Near East during the midto-late seventh century B.c. can be observed in two oxygen isotope records retrieved from lakes in the Zagros Mountains of western Iran. These data were obtained from the analysis of samples of authigenic, low-Mg calcite from the sediments of Lakes Mirabad and Zeribar (located in the southern and central Zagros Mountains, respectively). The geochronological sequence of the Mirabad lakebed sediments was based on three AMS ${ }^{14} \mathrm{C}$ dates obtained from charcoal samples, which yielded an average calibrated $1-\Sigma$ age range of approximately \pm 53 years (see Table 1 ; also Stevens et al. 2006: Table 1). At Mirabad, a modest increase in $\delta^{18} \mathrm{O}$ values (approximately $+0.4 \%$ ) took place between $c$. 850 B.C. $-c$. 650 B.C., after which conditions remained relatively stable for the remainder of the millennium (cf. ibid: fig. 4b). The $\delta^{18} \mathrm{O}$ value recorded for the latter date (which is approximately $-3.8 \%$ ), is slightly higher than that recorded during the peak of the arid phase for the previous millennium, indicating that despite the relatively minor enrichment in ${ }^{18} \mathrm{O}$ that took place between $850-650$ B.C., conditions in the southern Zagros were nevertheless characterized by considerable aridity at $c .650$ B.C.

The oxygen isotope record from Zeribar (also called Zarivar) is rather different from that of Mirabad. The first three centuries of the first millennium at Zeribar appear to have been a wet phase, after which a rapid shift towards moderately drier conditions in the vicinity is indicated by a rather sudden ${ }^{18} \mathrm{O}$ enrichment of approximately $+0.5 \%$ between $c .750-c .650$ B.C. After 650 B.C., a second abrupt increase in humidity occurred, which was followed by a further, equally sudden dry phase at approximately $500-400$ B.C. ${ }^{3}$ It should also be noted that the geochronological sequence of Zeribar is based on five bulk sediment radiocarbon dates that were initially obtained from the lake in the late 1960s, and was not calibrated until much later; moreover, as Stevens et al. note, these dates "are probably subject to errors related to hard-water effects" (2001: 750). Accordingly, while the Zeribar isotope proxy data do appear to reflect a trend rather similar to that which can be observed in the other records described above, this particular dataset should be considered with caution because of its uncertain chronology.

Historical evidence for aridification in the Near East during the mid-seventh century B.C.

It is unfortunate that the heartland of the Neo-Assyrian Empire - that is, the plains of northern Iraq and northeastern Syria - has thus far yielded comparatively little in terms of published paleoclimate proxy information for the seventh century B.c. This lack of empirical paleoclimatic evidence is especially regrettable considering that numerous studies have demonstrated that local conditions vary considerably even at short distances in this climatically-sensitive region (cf. Weiss 1983: 40; Çakırlar and Şeşen 2013). As a result, the Near Eastern paleoclimatic proxy evidence that is available to us can only be employed at present to identify broad regional trends in climate. Thus, although the proxy records discussed above do strongly indicate the existence of a regional shortterm dry phase during the seventh century B.C., the available paleoclimatic evidence does not reveal whether or how this regional climatic event was experienced within the Assyrian heartland region itself.

But although paleoclimatic proxy data for the Assyrian core area is lacking, this paucity can be partly surmounted, pending the availability of new empirical proxy data, by turning to historical accounts, particularly from the Neo-Assyrian textual corpus. Indeed, the Assyrian textual record

\footnotetext{
${ }^{3}$ A similar broad trend has also been noted by Altaweel et al. (2012: 6-7) in their recent survey of the Shahrizor plain.
} 
provides a tantalizing indication that the increased regional aridity revealed in paleoclimatic sequences from Anatolia, the Levant, and western Iran was also experienced in the Assyrian core area. Moreover, there are also indications that this climatic trend had real and significant impacts on Near Eastern populations and polities during the mid-seventh century B.C.

One primary source - an ancient letter dating to 657 B.C. which provides a glimpse of these impactsis particularly valuable. ${ }^{4}$ Addressed to the Assyrian king Assurbanipal (reigned 668-c. 630 B.C.), this letter was written by Akkulanu, an astrologer and an influential priest in the temple of Aššur, the national god of the Assyrian state (Parpola 1993: 76-78, Text 100). The dating of this document is secure because in the text Akkulanu reports several celestial phenomena he has observed during this year, including the heliacal rising of Mars, first visible around May 2, 657 B.c. (Iyyar 17 in the ancient Assyrian calendar), a solar eclipse on April 15 of the same year (Nisan 28 in the Assyrian calendar; the eclipse was seen partially in Nineveh, the Assyrian capital, and throughout the heartland of the Assyrian Empire in northern Iraq), and the visibility of Jupiter fifteen days after this same solar eclipse (Parpola 1983: 308-11). These astronomical phenomena, and Akkulanu's stated anticipation (Parpola 1993: 76-78, Text 100: r. 12) of the moon's visibility in the month of "Sivan" (i.e. May), mean that he wrote the letter to Assurbanipal on or shortly after Sivan 1 (i.e. May 15), 657 в.C. (Parpola 1983: 310-11).

This letter does not state Akkulanu's location when he wrote to the king, but the subject matter from his other letters indicates that he held a powerful position in the temple of Ašsur located in the city of that same name (Pearce and Radner 1998: 95-96). Aššr was situated at the southern extremity of the Assyrian heartland area. Akkulanu therefore probably wrote to Assurbanipal from his residence in Aššur, whereas the king resided in Nineveh, which lies approximately 100 kilometres north of Aššr. The two clay tablet fragments belonging to this letter were found in the royal palace archive of Nineveh.

In the text of the letter, Akkulanu discusses astrological interpretations that bear on two critical issues that faced Assurbanipal and his empire at the time it was written: the future of the Cimmeriansa nomadic and militarily powerful people who potentially threatened the Empire on its Anatolian frontier (Adalı 2011: 123-27), and the disastrous failure of the harvest in 657 в.C., which was apparently caused by an episode of severe drought, as Akkulanu notes (Parpola 1993: 77, Text 100: r. 1-4a):

\section{ù ina UGU A.AN.MEŠ $\check{s} a$ MU.AN.NA an-ni-ti im-țu-u-ni BURU ${ }_{14} \cdot \mathrm{MEŠ} l a$ in-né-piš-u-ni du-un-qu ša TI.LA ZI.2-MEŠ ša LUGAL EN-ía šu-u-tú}

And about this year's rains that were diminished and that no harvest was reaped; this is a good omen for the life and well-being of the king my lord.

The letter thus testifies that "Assyria experienced a serious economic setback in 657, the first harvest of the year being totally lost" (Parpola 1983: 307). The astrologer-priest, however, goes on to depict this disaster as a good omen for the future (Parpola 1993: 77, Text 100 r. 4b-11):

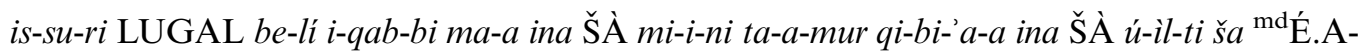
$m u$-šal-lim ša a-na ${ }^{\mathrm{md}}$ MES.SUM.PAB.MEŠ EN-šú

iš-pur-u-ni šá-tir

šum-ma GISKIM ina AN-e DU-kam-ma pi-iš-šá-tu la ir-ši šum-ma a-na ma-qa-at A.AN.MEŠ $i b-\check{s} i-k a^{\ulcorner} 3.20^{\urcorner}$KASKAL.MEŠ $n a-k i-r i$

šu-uṣ-bit [e]-ma DU-ku i-kaš-šad UD.MEŠ-šú GÍD.DA.MEŠ

Perhaps the king, my lord, will say: "Where did you see (that)? Tell me!"

In a report sent by Ea-mušallim to his lord Marduk-nadin-ahhe it is written: "If a sign occurs in the sky and cannot be cancelled,

\footnotetext{
${ }^{4}$ Although this letter was described briefly in our previous article (Schneider and Adalı 2014: 438), the text and its implications will be discussed in greater depth here.
} 
if it happens to you that the rains become scanty, make the king take the road against the enemy: He will conquer whatever (land) he will go to, and his days will become long."

Often, practitioners of astrology justified their predictions by citing standard omen collections which connected natural phenomena to predictions in clauses of protasis and apodosis, i.e. in "if-and-then" clauses (Koch-Westenholz 1995). The main astrological collection was the Enuma Anu Enlil (EAE). By the seventh century B.C., the collections were standardized bodies of omen texts, and were seen as repositories of authoritative knowledge (cf. Rochberg-Halton 1984; Hobson 2012). Precipitation was also among possible apodoses in the EAE. The astrologers would cite from the collections (Hunger 1992). Such letters were written in predetermined reporting formats, though certainly they answered specific queries of the king.

Akkulanu's letter deviates from standard Assyrian astrological reports in two significant and revealing ways. First of all, while the standard procedure was to only predict future natural phenomena, Akkulanu discusses an actual drought that had already occurred, which he then interprets astrologically for Assurbanipal. Secondly, instead of citing from the EAE and related materials, in crafting his response to Assurbanipal's query, Akkulanu uniquely quotes a by-then centuries-old archived astrological report that was apparently written by a certain astrologer named Ea-mušallim to Marduk-nahin-ahhe, an ancient king of Babylonia who reigned between 1098-1081 B.c. (near the end of the Middle Babylonian period; cf. Brinkman 1968: 123). Eamušallim and his letter are known presently only from Akkulanu's allusion to them in his own letter to Assurbanipal. It is noteworthy that Akkulanu went beyond the usual sources to find a much older interpretation in the Middle Babylonian astrological corpus that would encourage the king in light of the unfolding disaster, which must have widely been seen as a bad omen. Presumably, he must have done so to ease Assurbanipal's anxieties regarding the severity of the 657 B.C. drought event in the Assyrian heartland.

It is a great stroke of fortune that today we can read Akkulanu's description of the drought that occurred in the Assyrian heartland in 657 B.c. Such incidents would presumably have been reported in official state communications, but the texts available to us today are not representative, as they are but a small fraction of the original corpus, and thus comprise an unrepresentative and incomplete dataset concerning various aspects of Assyrian history. One reason for this is the shift from clay tablets to perishable materials after Sargon II's reign (Parpola 1981: 122-23; Radner 2014: 83-26). Moreover, the presently known letters are unevenly distributed among the reigns of Adad-nirari III (810-783 в.C.), Tiglath-pileser III (744-727 в.с.), Sargon II (721-705 в.C.), Sennacherib (704-681 в.с.), Esarhaddon (680-669 в.с.), Assurbanipal (668-c. 630 в.C.), Sin-šarruiškun (c. 626-612 в.C.), and Aššur-uballit II (c. 611-609 B.C.); most of them date to certain periods of the reigns of Sargon II, Esarhaddon, and Assurbanipal (cf. Radner 2014).

In addition to the Neo-Assyrian textual corpus, there are also a total of around 19,000 NeoBabylonian tablets, which date from the late seventh, sixth and early fifth centuries B.C. However, many of these are still unpublished or unread, and the bulk of the material is from Babylon, Borsippa, Nippur, Sippar and Uruk, and mostly from the sixth and early fifth centuries B.C. (Jursa 2010a: 7-8). The final decades of the seventh century B.C. yield only small groups of tablets, mostly with a private and non-state background (Nielsen 2008). These-insofar as they have been read-provide limited information about economic history in Babylonia (Jursa 2010a: 8, n.43). There are texts from the reign of Nabonidus (556-539 B.c.) concerning Neo-Babylonian agricultural activity in the Khabur Basin, but these provide no information about that region's agricultural productivity during the late seventh century B.C., or about any potential impacts of climate upon agriculture in the Khabur during the final decades of the Neo-Assyrian period (Jursa 2010b: 96, n.172; Jursa and Wagensonner 2014). Thus, to the best of our knowledge, there is no known Neo-Babylonian text providing information about agriculture and climate in late seventh century Assyria.

Within the corpus of texts that we do have, discussions of climatic conditions or events are relatively rare. Apart from Akkulanu's letter to Assurbanipal, there are a handful of other texts, 
virtually all of which date from the reign of Sargon II. Most of these documents report that rainfall was comparatively plentiful (e.g., Parpola 1987: 79, Text 92: r.11-12; Fuchs and Parpola 2001: 6, Text 4: r.7-9, also 7, Text 6: 4-8, r.2-7): in only three cases is drought discussed in the royal correspondence of Sargon II's reign. In one such case, Ašipa, governor of Tušhan (the site of Ziyaret Tepe in southeastern Turkey), reported that there was no rainfall for the month of Tammuz (i.e. June-July) and that water was scarce (Lanfranchi and Parpola 1993: 18, Text 21: r.3-4). In a second, very fragmentary letter (the name of the sender is lost, but the content hints at it being written by the same governor), it is stated more strongly that it did not rain or snow and so there is no water in the river (ibid: $21-22$, Text 26: 9-r.1). Finally, another fragmented letter (sender unknown) informs Sargon II that the river running past Samaria in Palestine had dried up and the area was facing a period of severe drought (Parpola 1987: 198, Text 255; Radner 2000: 236). These are, to our knowledge, the only documents to provide an observation of drought during the reign of Sargon II; otherwise, only Akkulanu's letter provides any description of an actual instance of drought.

Paleoclimatic and historical evidence for a "Late Assyrian Dry Phase" (c. 650-c. 600 B.C.)

Evidence for relatively high aridity during the seventh century B.C., and especially during its latter half, was observed in all of the paleoclimate proxy records from the Near East. Of the four paleoclimate proxy indicators that were inferred from the geochemical composition of sediments within stratigraphic core samples, two (the records from Iznik and Tecer) exhibit a climatic shift to drier conditions at approximately 650 B.C., while the shift to drier conditions took place slightly earlier in the Dead Sea (c. 690 B.C.), and slightly later in the Rumailiah River (shortly before 600 B.C.). At Tecer this shift was relatively short-lived, whereas in the Iznik sequence and the Dead Sea the dry phase lasted for multiple centuries. Unfortunately, because the Rumailiah River sequence ends at c. 600 B.C., it is not possible to determine the duration of this drier phase from the extant sediment record.

The onset of drier conditions during the latter half of the seventh century B.c. that is demonstrated by the four sediment composition proxy indicators is also reflected in the oxygen isotope records from Eski Acıgöl, Soreq Cave and Lakes Mirabad and Zeribar. At Soreq, very high $\delta^{18} \mathrm{O}$ values were observed throughout the middle centuries of the millennium, which appear to have reached a peak at $c .450$ B.C. A sharp increase in $\delta^{18} \mathrm{O}$ values at Zeribar beginning at $c .750$ B.C. reached its peak at c. 650 B.C. At both Eski Acıgöl and Lake Mirabad, on the other hand, a more gradual increase in $\delta^{18} \mathrm{O}$ values beginning at $c .850$ B.C. reached its peak at approximately 600 B.C.

Taken together, the timing of peak aridity or of a shift towards greater aridity in these various sources of paleoclimate proxy information appears to indicate that a short-term dry phase occurred between 650-600 в.с. (see Fig. 2). The agreement between these proxy records strongly suggests that much of the Near East experienced this climatic perturbation. However, we must also point out that there is a fair amount of chronological uncertainty for some of the proxy records employed here, such as the Eski Acigöl isotope record, and the Lake Zeribar and Rumailiah River sedimentary archives. Moreover, a comparatively small number of the geochronological dates used to establish the sequences of the proxy records discussed here date to the first millennium B.c. (see Table 2). We cannot, therefore, rule out the possibility that the agreement of the proxy records concerning the onset of increased aridity in the Near East between c. 650-600 в.C. is at least partly an artefact of geochronological dating error for these paleoclimate proxy archives. Having said that, because evidence for relatively high aridity during the mid-to-late seventh century B.C. can be observed in all eight records, including those with more robust chronologies that exhibit relatively small calibrated age ranges, we maintain that the overall pattern indicated by the proxy records is more likely a reflection of a regional climatic perturbation in the Near East during this period. Furthermore, in addition to the data described here, this hypothesis has also received further support from the results of another recently published reconstruction of Holocene conditions in the Mediterranean Basin and Southern Europe (Guiot and Kaniewski 2015), which found that there is a high probability that arid conditions prevailed in the southeastern Mediterranean Basin during the Late Assyrian Dry Phase (ibid: 14, also fig. 12A). 


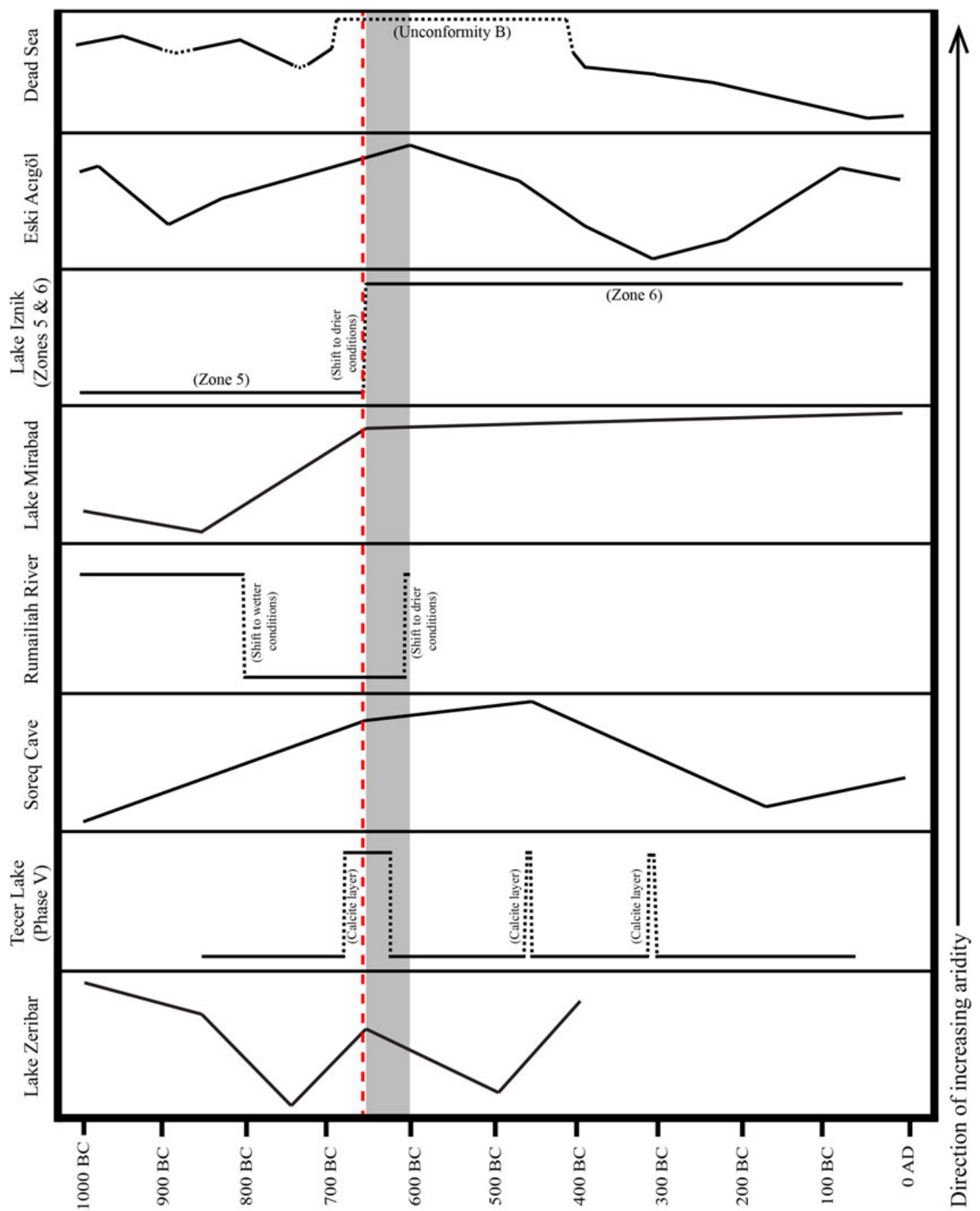

Fig. 2 A graph of climate trends during the first millennium B.c., as inferred from local paleoclimate proxy records. The shaded area corresponds to the proposed duration of the Late Assyrian Dry Phase, while the vertical dashed line represents the 657 B.C. drought in the Assyrian heartland discussed in Akkulanu's letter to Assurbanipal

The various paleoclimate proxy data described above provide the empirical paleoenvironmental context for Akkulanu's primary historical account of a major drought event in the Assyrian heartland of northern Iraq, which took place in 657 B.c. This historical evidence is significant on two levels: not only does the timing of the drought event correspond well with the climatic 
TABLE 2. A list of the chronometric determinants that date to the first millennium B.C., as reported in the original paleoclimate studies

\begin{tabular}{|c|c|c|c|c|c|}
\hline Site & Type & Cal. Mean Age & 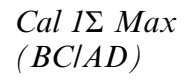 & 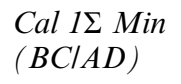 & Source \\
\hline Dead Sea & AMS & $2518 \pm 35 \mathrm{BP}$ & $650 \mathrm{BC}$ & $540 \mathrm{BC}$ & $\begin{array}{l}\text { Bookman (Ken-Tor) et al } \\
\text { 2004: Table } 1\end{array}$ \\
\hline Dead Sea & AMS & $1990 \pm 40 \mathrm{BP}$ & $45 \mathrm{BC}$ & $30 \mathrm{AD}$ & $\begin{array}{l}\text { Bookman (Ken-Tor) et al } \\
\text { 2004: Table } 1\end{array}$ \\
\hline Dead Sea & AMS & $2120 \pm 40 \mathrm{BP}$ & $115 \mathrm{BC}$ & $40 \mathrm{BC}$ & $\begin{array}{l}\text { Bookman (Ken-Tor) et al } \\
\text { 2004: Table } 1\end{array}$ \\
\hline Dead Sea & AMS & $2050 \pm 40 \mathrm{BP}$ & $120 \mathrm{BC}$ & $75 \mathrm{BC}$ & $\begin{array}{l}\text { Bookman (Ken-Tor) et al } \\
\text { 2004: Table } 1\end{array}$ \\
\hline Dead Sea & AMS & $2120 \pm 30 \mathrm{BP}$ & $180 \mathrm{BC}$ & $110 \mathrm{BC}$ & $\begin{array}{l}\text { Bookman (Ken-Tor) et al } \\
\text { 2004: Table } 1\end{array}$ \\
\hline Dead Sea & AMS & $2230 \pm 30 \mathrm{BP}$ & $320 \mathrm{BC}$ & $200 \mathrm{BC}$ & $\begin{array}{l}\text { Bookman (Ken-Tor) et al } \\
\text { 2004: Table } 1\end{array}$ \\
\hline Dead Sea & AMS & $2190 \pm 30 \mathrm{BP}$ & $360 \mathrm{BC}$ & $280 \mathrm{BC}$ & $\begin{array}{l}\text { Bookman (Ken-Tor) et al } \\
\text { 2004: Table } 1\end{array}$ \\
\hline Dead Sea & AMS & $2485 \pm 40 \mathrm{BP}$ & $600 \mathrm{BC}$ & $500 \mathrm{BC}$ & $\begin{array}{l}\text { Bookman (Ken-Tor) et al } \\
\text { 2004: Table } 1\end{array}$ \\
\hline Dead Sea & AMS & $2445 \pm 34 \mathrm{BP}$ & $760 \mathrm{BC}$ & $680 \mathrm{BC}$ & $\begin{array}{l}\text { Bookman (Ken-Tor) et al } \\
\text { 2004: Table } 1\end{array}$ \\
\hline Dead Sea & AMS & $2715 \pm 42 \mathrm{BP}$ & $900 \mathrm{BC}$ & $820 \mathrm{BC}$ & $\begin{array}{l}\text { Bookman (Ken-Tor) et al } \\
\text { 2004: Table } 1\end{array}$ \\
\hline Dead Sea & AMS & $2775 \pm 37 \mathrm{BP}$ & $1000 \mathrm{BC}$ & $890 \mathrm{BC}$ & $\begin{array}{l}\text { Bookman (Ken-Tor) et al } \\
\text { 2004: Table } 1\end{array}$ \\
\hline Dead Sea & AMS & $2163 \pm 27 \mathrm{BP}$ & $205 \mathrm{BC}$ & $150 \mathrm{BC}$ & $\begin{array}{l}\text { Bookman (Ken-Tor) et al } \\
\text { 2004: Table } 3\end{array}$ \\
\hline Dead Sea & AMS & $2128 \pm 27 \mathrm{BP}$ & $210 \mathrm{BC}$ & $150 \mathrm{BC}$ & $\begin{array}{l}\text { Bookman (Ken-Tor) et al } \\
\text { 2004: Table } 3\end{array}$ \\
\hline Iznik & AMS & $2246 \pm 119$ BР & $356 \mathrm{BC}$ & $236 \mathrm{BC}$ & Ülgen et al 2012: Table 3 \\
\hline Iznik & AMS & $2085 \pm 43.5 \mathrm{BP}$ & $157 \mathrm{BC}$ & $113 \mathrm{BC}$ & Ülgen et al 2012: Table 3 \\
\hline Rumailiah & AMS & $2850 \mathrm{BP}$ & $920 \mathrm{BC}$ & $840 \mathrm{BC}$ & $\begin{array}{l}\text { Kaniewski et al 2008: } \\
\text { Table } 1\end{array}$ \\
\hline Soreq Cave & TIMS & $2098 \pm 33$ BР & N/A & N/A & $\begin{array}{l}\text { Bar-Matthews et al 2000: } \\
\text { Table } 2\end{array}$ \\
\hline Tecer & AMS & $2875 \mathrm{BP}$ & $981 \mathrm{BC}$ & $895 \mathrm{BC}$ & $\begin{array}{l}\text { Kuzucuoglu et al 2011: } \\
\text { Table } 2\end{array}$ \\
\hline Tecer & AMS & $2810 \mathrm{BP}$ & $856 \mathrm{BC}$ & $824 \mathrm{BC}$ & $\begin{array}{l}\text { Kuzucuoglu et al 2011: } \\
\text { Table } 2\end{array}$ \\
\hline Tecer & AMS & $2020 \mathrm{BP}$ & $111 \mathrm{BC}$ & $4 \mathrm{AD}$ & $\begin{array}{l}\text { Kuzucuoglu et al 2011: } \\
\text { Table } 2\end{array}$ \\
\hline Zeribar & $14 \mathrm{C}$ & $\begin{array}{l}2240 \pm 150 \mathrm{BP} \\
\text { (uncalibrated) }\end{array}$ & $360 \mathrm{BC}$ & $260 \mathrm{BC}$ & Stevens et al 2001: Table 1 \\
\hline
\end{tabular}

evidence for aridification, but it also suggests that drier conditions affected a region, namely the Tigris Valley in northern Iraq, for which the paleoclimate record is at present virtually non-existent. Obviously, this allusion to a drought in a single document cannot be considered empirical evidence of a shift towards drier conditions in the Assyrian heartland during the mid-to-late seventh century B.C., but considering how well the historical record correlates with the timing of the dry phase which has been recorded in paleoclimate archives to the immediate north and east of the area, Akkulanu's letter is highly suggestive that this was indeed the case, pending the availability of further paleoclimate information for the area.

To our knowledge, the content of Akkulanu's letter is unique in that it not only establishes that there was a drought in 657 в.C., but also gives some indication of its intensity. From Akkulanu's description of the failed harvest which resulted from it, it seems clear that the drought event in 657 B.C. was severe, particularly in light of the fact that by this time the Assyrian state had constructed 
an extensive network of canals throughout their heartland in the Middle Tigris Valley, and in some other areas under Assyrian control, to supplement the traditional system of rain-fed agriculture with an additional supply of water (cf. Ur 2005). While such a precipitous drop in annual rainfall might seem implausible, it would certainly not be unique in this region; for example, an intense drought in 2007-2009 caused precipitation levels to decline by approximately forty per cent in most of the Fertile Crescent during that span, and as much as seventy per cent in central Iraq (Trigo et al. 2010: 1246).

It is possible that the severe drought noted by Akkulanu in 657 B.C. was an isolated phenomenon, but as noted above, the recent climate history of the Near East suggests otherwise. In Turkey, there were four major dry periods between 1930 and 1993. During this sixty-three-year span, severe nationwide drought events occurred in four years; all four of these severe and widespread droughts took place during multi-year periods of drier conditions. In a more extreme example, during a thirty-year period of dry conditions from 1980-2010, Iraq experienced significant droughts that affected at least one or two regions of the country in half of that period, of which four were so severe that they afflicted the entirety of Iraq (Al-Timimi and Al-Jiboori 2013). In neither the Turkish nor the Iraqi case were severe droughts reported in isolation; they occurred without exception as part of multi-year dry periods during which drought events of varying severity were relatively frequent. Moreover, it can be observed in these same drought records that the tendency of severe droughts to occur within larger dry spells also applies in the case of droughts which afflicted much if not all of the larger region. Although the dry phases within these records only overlap for a nine year period that took place between 1982-1993 (excepting 1987-1988, which were not dry years in Turkey), severe nationwide drought events were observed in both countries in three of those years $(1983,1989$, and 1990). Thus, given the tendency for drought events to cluster in dry periods in the modern Near East, and the high likelihood that drought events in the seventh century B.C. would have similar characteristics to those of the region today, we consider it unlikely that a severe drought event, such as the one that occurred in 657 B.C., would have occurred as an isolated incident within an otherwise humid period.

\section{Conclusions and future directions}

In this paper, we have attempted to demonstrate that multiple paleoclimate proxy records from Anatolia, the Levant, and western Iran do provide evidence for a relatively short-lived episode of increased aridity - which we term the Late Assyrian Dry Phase - in the Near East from c. 650-c. 600 B.C. Most of the paleoclimatic proxy data discussed here indicate that aridity in this period appears to have reached its greatest intensity at approximately 650 B.C., while peak aridity was reached somewhat earlier in the Dead Sea (at $c .690$ B.C.), somewhat later in the Rumailiah River sedimentary archive (at $c .600$ B.C.), and even later in the Soreq Cave isotope sequence (c. 450 B.C.). In general, though, the overall pattern of desiccation during the mid-first millennium B.C., and particularly during the seventh century, is evident in multiple sources of proxy information from different regions of the Near East. Given the agreement between the different proxy records discussed here-particularly as they correlate well with the Assyrian report of severe drought during roughly the same period - it seems highly likely that most if not all of the intervening areas in this climatically-sensitive region experienced unusually arid climatic conditions between 650 600 B.C.

While we have given the dates 650-600 B.C. as the duration of the Late Assyrian Dry Phase, we acknowledge that arguments in favour of a slightly different chronology could also be made based on the evidence presented in this article. In particular, the Dead Sea hiatus could be grounds for potentially placing the onset of this dry phase at 700 в.C., whereas a later termination date for this event might be proposed on the basis of the intensely dry conditions at Soreq from c. 650-c. 450 B.C. Ultimately, we chose to err on the side of caution in assigning our dates for this event, basing our chronology for the Late Assyrian Dry Phase on dates for which a clear majority of the paleoclimatic sequences employed in our analysis showed evidence of greater aridity.

Finally, we have chosen to call the climate event that we highlight in this paper the "Late Assyrian Dry Phase" because the paleoclimatic evidence appears to suggest that much of the Near East at the 
same time as the Assyrian Empire - and several other polities in the northern Near East, such as the Kingdom of Urartu (Grekyan 2013-2014) - experienced a sudden, rapid decline during this same period. But although (as we have previously argued) this correlation is suggestive, more work is required to understand the precise nature of any connections between aridification and the political disintegration of those societies. It will also be necessary to identify the other important causal factors that also played key roles in shaping the tumultuous course of historical events in the region during the late seventh century B.C. We sincerely hope that further archaeological, historical, and paleoclimatological research will delve into the matter in the future.

\section{References}

Adal, S.F. 2011. The Scourge of God: The Umman-manda and Its Significance in the First Millennium BC. Helsinki: The Neo-Assyrian Text Corpus Project.

Al-Timimi, Y.K. and M.H. Al-Jiboori. 2013. Assessment of spatial and temporal drought in Iraq during the period 1980-2010. International Journal of Energy and Environment 4: 291-302.

Altaweel, M., A. Marsh, S. Mühl, O. Nieuwenhuyse, K. Radner, K. Rasheed and S.A. Saber. 2012. New Investigations in the Environment, History, and Archaeology of the Iraqi Hilly Flanks: Shahrizor Survey Project 2009-2011. Iraq 74/3: 1-35.

Ayalon, A., M. Bar-Matthews and A. Kaufman. 2002. Climatic conditions during marine isotopic stage 6 in the Eastern Mediterranean region as evident from the isotopic composition of speleothems: Soreq Cave, Israel. Geology 30: 303-06.

Bar-Matthews, M., A. Ayalon and A. Kaufman. 2000. Timing and hydrological conditions of Sapropel events in the Eastern Mediterranean, as evident from speleothems, Soreq Cave, Israel. Chemical Geology 169: 145-56.

Bar-Matthews, M, A. Ayalon, M. Gilmour, A. Matthews and C.J. Hawkesworth. 2003. Sea-land oxygen isotopic relationships from planktonic foraminifera and speleothems in the Eastern Mediterranean region and their implication for paleorainfall during interglacial intervals. Geochimica et Cosmochimica Acta 67: 3181-99.

Bookman (Ken-Tor), R., Y. Enzel, A. Agnon and M. Stein. 2004. Late Holocene lake levels of the Dead Sea. Geological Society of America Bulletin 116: 555-71.

Brinkman, J.A. 1968. A Political History of Post-Kassite Babylonia. Rome: Pontificio Istituto Biblico.

Çakırlar, C. and R. Şeşen. 2013. Reading between the lines: $\delta 18 \mathrm{O}$ and $\delta 13 \mathrm{C}$ isotopes of Unio elongatulus shell increments as proxies for local palaeoenvironments in mid- Holocene northern Syria. Archaeological and Anthropological Sciences 5: 85-94.

Cline, E.H. 2014. 1177 B. C.: The Year Civilization Collapsed. Princeton, NJ: Princeton University Press.

Cullen, H. and P.B. deMenocal. 2000. North Atlantic Influence on Tigris-Euphrates Streamflow. International Journal of Climatology 20: 853-63.

Cullen, H.M., P.B. deMenocal, S. Hemming, F.H. Brown, T. Guilderson and F. Sirocko. 2000. Climate Change and the Collapse of the Akkadian Empire: Evidence from the Deep Sea. Geology 28: 379-82.

Cullen, H., A. Kaplan, P.A. Arkin, P.B. deMenocal. 2002. Impact of the North Atlantic Oscillation on Middle Eastern Climate and Streamflow. Climatic Change 55: 315-38.

Dansgaard, W. 1964. Stable isotopes in precipitation. Tellus 16: 436-68.

Fuchs, A. and S. Parpola. 2001. The Correspondence of Sargon II, Part III: Letters from Babylonia and the Eastern Provinces. Helsinki: Helsinki University Press (State Archives of Assyria 15).

Gat, J.R. 1996. Oxygen and Hydrogen Isotopes in the Hydrologic Cycle. Annual Review of Earth and Planetary Sciences 24: 225-62.

Grekyan, Y. 2013-2014. When the Gods Leave People (The Climatological Hypothesis of the Collapse of the Urartian State). Aramazd: Armenian Journal of Near Eastern Studies 8: 57-94.

Guiot, J and D. Kaniewski. 2015. The Mediterranean Basin and Southern Europe in a warmer world: what can we learn from the past? Frontiers in Earth Science 3 (Article 28): 1-16. doi: 10.3389/feart.2015.00028

Hobson, R. 2012. Transforming Literature into Scripture: Texts as Cult Objects at Nineveh and Qumran. Sheffield/Bristol, CT: Equinox.

Hunger, H. 1992. Astrological Reports to Assyrian Kings. Helsinki: Helsinki University Press (State Archives of Assyria 15).

Jones, M.D., C.N. Roberts. 2008. Interpreting lake isotope records of Holocene environmental change in the Eastern Mediterranean. Quaternary International 181: 32-38.

Jursa, M. 2010a. Aspects of the Economic History of Babylonia in the First Millennium BC. Economic Geography, Economic Mentalities, Agriculture, the Use of Money and the Problem of Economic Growth. Münster: Ugarit-Verlag. Münster.

— 2010b. Der neubabylonische Hof. Pp. 67-106 in: B. Jacobs and R. Rollinger (eds.), Der Achämenidenhof / The Achaemenid Court. Akten des 2. Internationalen Kolloquiums zum Thema »Vorderasien im 
Spannungsfeld klassischer und altorientalischer Überlieferungen« Landgut Castelen bei Basel, 23.-25. Mai 2007. Wiesbaden. Harrassowitz Verlag.

Jursa, M, and K. Wagensonner. 2014. The Estates of Šamaš on the Huābūr. Pp. 109-30 in M. Kozuh, W.F.M. Henkelman, C.E. Jones and C. Woods (eds.), Extraction \& Control. Studies in Honor of Matthew W. Stolper. Chicago: Oriental Institute.

Kaniewski, D., E. Paulissen, E. Van Campo, M. Al-Maqdissi, J. Bretschneider and K. Van Lerberghe. 2008. Middle East coastal ecosystem response to middle-to-late Holocene abrupt climate changes. Proceedings of the National Academy of Sciences 105: 13941-46.

Kaniewski, D., E. Paulissen, E. Van Campo, H. Weiss, T. Otto, J. Bretschneider and K. Van Lerberghe. 2010. Late second-early first millennium BC abrupt climate changes in coastal Syria and their possible significance for the history of the Eastern Mediterranean. Quaternary Research 74: 207-15.

Katsoulis, B.D., T.J. Makrogiannis, Y.A. Goutsidou. 1998. Monthly Anticyclonicity in Southern Europe and the Mediterranean Region. Theoretical and Applied Climatology 59: 51-59.

Koch-Westenholz, U. 1995. Mesopotamian Astrology: An Introduction to Babylonian and Assyrian Celestial Divination. Copenhagen: Museum of Tusculanum Press (CNI Publications 19. The Carsten Niebuhr Institute of Near Eastern Studies).

Kuzucuoğlu, C., W. Dörfler, S. Kunesch, F. Goupille. 2011. Mid- to late-Holocene climate change in central Turkey: The Tecer Lake record. The Holocene 21: 173-88.

Lanfranchi, G.B. and S. Parpola. 1993. The Correspondence of Sargon II, Part II: Letters from the Northern and Northeastern Provinces. Helsinki: Helsinki University Press (State Archives of Assyria 5).

Neumann, J. and S. Parpola. 1987. Climatic Change and the Eleventh-Tenth-Century Eclipse of Assyria and Babylonia. Journal of Near Eastern Studies 46: 161-82.

Nielsen, J.P. 2008. Sons and Descendants: a Social History of Kin Groups and Family names in the Early NeoBabylonian Period. PhD Dissertation. University of Chicago.

Pearce, L. and K. Radner 1998. Akkulānu. Pp. 95-96 in K. Radner (ed.), The Prosopography of the Neo-Assyrian Empire 1/I: A. Helsinki: The Neo-Assyrian Text Corpus Project.

Parpola, S. 1981. Assyrian Royal Inscriptions and Neo-Assyrian Letters. Pp. 117-42 in F.M. Fales (ed.), Assyrian Royal Inscriptions: New Horizons in Literary, Ideological and Historical Analysis. Papers of a symposium held in Catona (Siena), June 26-28, 1980. Rome: Istituto per l'Oriente (Orientis Antiqui Collection 17).

- 1983. Letters from Assyrian Scholars to the Kings Esarhaddon and Assurbanipal, Part II: Commentary and Appendices. Neukirchen-Vluyn: Butzon \& Bercker (Alter Orient und Altes Testament 5/2).

- 1987. The Correspondence of Sargon II, Part I: Letters from Assyria and the West. Helsinki. Helsinki University Press (State Archives of Assyria 1).

- 1993. Letters from Assyrian and Babylonian Scholars. Helsinki: Helsinki University Press (State Archives of Assyria 10).

Radner, K. 2000. How did the Neo-Assyrian King Perceive his Land and its Resources? Pp. 233-46 in R.M. Jas (ed.), Rainfall and Agriculture in Northern Mesopotamia: Proceedings of the 3rd MOS Symposium, Leiden, May 21-22, 1999. Leiden: The Netherlands Nederlands Instituut voor het Nabije Oosten.

Radner, K. 2014. An Imperial Communication Network: The State Correspondence of the Neo-Assyrian Empire. Pp. 64-93 in K. Radner (ed.), State Correspondence in the Ancient World: From New Kingdom Egypt to the Roman Empire. Oxford: Oxford University Press.

Roberts, N., J.M. Reed, M.J. Leng, C. Kuzucuoğlu, M. Fontugne, J. Bertaux, H. Woldring, S. Bottema, S. Black, E. Hunt and M. Karabiyikoğlu. 2001. The tempo of Holocene climatic change in the eastern Mediterranean region: new high-resolution crater-lake sediment data from central Turkey. The Holocene 11: 721-36.

Roberts, N., D. Brayshaw, C. Kuzucuoğlu, R. Perez and L Sadori. 2011. The mid-Holocene climatic transition in the Mediterranean: Causes and consequences. The Holocene 21: 3-13.

Rochberg-Halton, F. 1984. Canonicity in Cuneiform Texts. Journal of Cuneiform Studies 36: 127-44.

Schneider, A.W. and S.F. Adal1. 2014. "No harvest was reaped": demographic and climatic factors in the decline of the Neo-Assyrian Empire. Climatic Change 127/3-4: 435-46

Stevens, L.R. and H.E. Wright Jr. and E. Ito. 2001. Proposed changes in seasonality of climate during the Lateglacial and Holocene at Lake Zeribar, Iran. The Holocene 11: 747-55.

Stevens, L.R., E. Ito, A. Schwalb and H.E. Wright Jr. 2006. Timing of atmospheric precipitation in the Zagros Mountains inferred from a multi-proxy record from Lake Mirabad, Iran. Quaternary Research 66: 494-500.

Trigo, R.M., C.M. Gouveia and D. Barriopedro. 2010. The intense 2007-2009 drought in the Fertile Crescent: Impacts and associated atmospheric circulation. Agricultural and Forest Meteorology 150: $1245-57$. 
Türkeş, M. 1996. Meteorological drought in Turkey: a historical perspective, 1930-1993. Drought Network News 8: $17-21$.

- 1998. Influence of Geopotential Heights, Cyclone Frequency and Southern Oscillation on Rainfall Variations in Turkey. International Journal of Climatology 18: 649-90.

Ülgen, U.B., S.O. Franz, D. Biltekin, M.N. Çagatay, P.A. Roeser, L. Doner and J. Thein. 2012. Climatic and environmental evolution of Lake Iznik (NW Turkey) over the last 4700 years. Quaternary International 274: 88-101.

Ur, J. 2005. Sennacherib's Northern Assyrian Canals: New Insights from Satellite Imagery and Aerial Photography. Iraq 67: 317-45.

Weiss, H. 1983. Excavations at Tell Leilan and the Origins of North Mesopotamian cities in the Third Millennium B.C. Paléorient 9/2: 39-52.

Weiss, H., M-A. Courty, W. Wetterstrom, F. Guichard, L. Senior, R. Meadow and A. Curnow. 1993. The Genesis and Collapse of Third Millennium North Mesopotamian Civilization. Science 261: 995-1004.

Wilkinson, T.J. 1990. Town and Country in Southeastern Anatolia, Vol 1: Settlement and Land Use at Kurban Höyük and Other Sites in the Lower Karababa Basin. Chicago: Oriental Institute Publications.

- 2000. Settlement and Land Use in the Zone of Uncertainty in Upper Mesopotamia. Pp. 3-36 in R.M. Jas (ed.), Rainfall and Agriculture in Northern Mesopotamia. Leiden: Nederlands Instituut voor het Nabije Oosten.

Adam W. Schneider

Cooperative Institute for Research in Environmental Sciences

University of Colorado-Boulder

$216 \mathrm{UCB}$

Boulder, CO,

USA 80309-0216

schneiaw@colorado.edu

Selim F. Adalı

Department of History

Social Sciences University of Ankara

$$
\text { براهين إضافية عن "مرحلة آثورية متأخرة جافة" في الشرق الأدنى خلال فترة منتصف الى أواخر القرن السابع قبل الميلاد }
$$

في مقالة سابقة نشرت مؤخرا في مجلة التغير المناخي Climatic Change طرحنا نظرية تقول بأن الجفاف والزيادة العفرطة في عدد السكان لعبتا

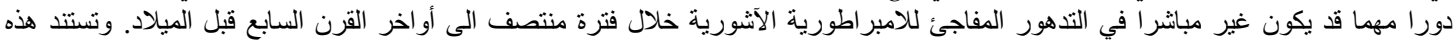

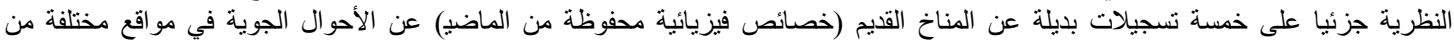

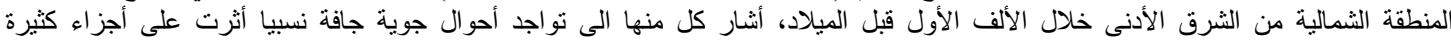

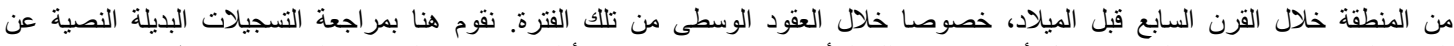

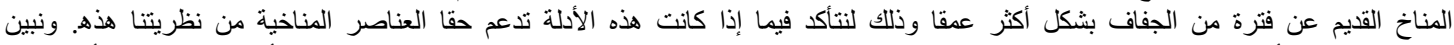

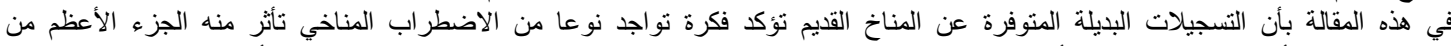

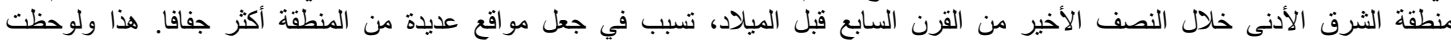

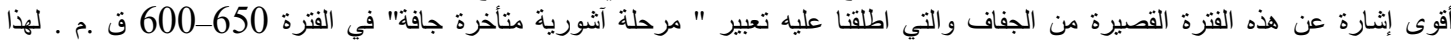
فأن هذه التسجيلات البديلة تدعم النظرية وتزدنا بخلفية للأدلة النصية الآشورية الحديثة عن وجود جفاف خلال فتل فترة منتصف الى أواخر القرن 